\title{
Wall Surfaces as Interfaces: The First Pompeian Style
}

\author{
Annette Haug
}

Citation: Haug, Annette. 2022. Wall Surfaces as Interfaces: The First

Pompeian Style. Arts 11: 16.

https://doi.org/10.3390/

arts11010016

Academic Editors: Elizabeth Molacek and Vanessa Rousseau

Received: 13 October 2021

Accepted: 29 December 2021

Published: 11 January 2022

Publisher's Note: MDPI stays neutral with regard to jurisdictional claims in published maps and institutional affiliations.

Copyright: (C) 2022 by the author Licensee MDPI, Basel, Switzerland. This article is an open access article distributed under the terms and conditions of the Creative Commons Attribution (CC BY) license (https:// creativecommons.org/licenses/by/ $4.0 /)$.
Institute of Classical Archaeology, Christian-Albrechts-Universität zu Kiel, 24118 Kiel, Germany; ahaug@klassarch.uni-kiel.de

\begin{abstract}
This article investigates the role of wall surfaces as an interactive medium in the First Pompeian Style, referring to examples from Pompeii. Five different aspects are investigated in more detail: (1) surfaces and their relation to the core; (2) surface qualities; (3) surfaces as image carriers; (4) surfaces and their relation to the physical space; (5) surfaces and their relation to the social space. These aspects allow for a deeper understanding of the First Style's ornamental, pictorial and spatial qualities. In this view, surfaces can be conceived as media interfaces.
\end{abstract}

Keywords: wall surfaces; Pompeii; first style; interfaces; atmospheres; ornaments; images; perception

\section{Introduction}

Humans encounter the world through surfaces. In enclosed spaces, these are the surfaces of floors, walls, and ceilings, and for people and animals, these surfaces are represented and experienced by skin and hair. ${ }^{1}$ Surfaces function as medially and materially defined interfaces of communication and interaction. Thus, it is unsurprising that aesthetic work is primarily invested through the design of surfaces, ${ }^{2}$ which act as carriers of decoration. In the following paper, I focus on different aspects of the qualities of wall surfaces of the so-called First Style of the second and early first century BCE, referring to case studies from Pompeii.

Previous research has mostly looked at this form of wall design with regard to its regional origins, its chronology, its technology, its (regionally specific) formal structure and specific design features (e.g., mock architecture or pictorial friezes), but also in view of the relation between the size of the house, the size of the room and the decorative schemes used. ${ }^{3}$ However, a differentiated discussion from a more theoretical perspective is still lacking. ${ }^{4}$ In the following, the analysis focuses on the pictorial, ornamental and spatial qualities of First Style wall surfaces to gain an understanding of their media qualities.

When we speak of ornament and image, these are modern terms. ${ }^{5}$ Nevertheless, various strategies for the production of pictoriality and ornamentality can already be seen in antiquity-and more concretely in the First Style. These strategies include the relations of semantically stronger (more complex) and weaker elements (e.g., figural representations versus vegetal motifs), singular and repetitive elements, centrality and marginality, framed and unframed elements, different sizes of representations, and different volumes for one representation (i.e., two-dimensional versus three-dimensional). ${ }^{6}$ All of these approaches were already used in the First Style, resulting in multiple interweavings of image and ornament. Despite this interconnectedness of ornamental and pictorial effects, we can also use these terms to characterize the different media strategies.

The following subchapters each highlight various contexts in which imagery, ornamentation and space come into play: (1) surfaces and their relation to the (architectural) core; (2), surface qualities; (3) surfaces as image carriers; (4) surfaces and their relation to the physical space; (5) surfaces and their relation to the social space. Despite all regional variances of the First Style, the phenomena observed in the Pompeiian material have more general importance: They allow for an understanding of First-Style media qualities. In the 
conclusion, the observations made on the material are therefore related to a more general media-theoretical perspective.

\section{Surface and Core: First Style Stucco as an Ideal Image of a Wall}

In the First Style, the wall is coated with stucco, which presents the image of a luxurious wall. ${ }^{7}$ This process is done by modelling, in relief, a regular sequence of plinth, socle, horizontal bands (fascia), large horizontal or vertical orthostates, rows of ashlars, epistyles, and upper zones (see below, Figures 2, 4-6, 11 and 12). The relationship of such a 'wall' to the supporting wall structure always remains entirely fictive-the real wall, especially in domestic architecture, usually consists of a simple opus incertum. However, the wall image pretends to be the real wall through the absence of a framing device (which serves as one potential indicator of pictoriality) ${ }^{8}$ through its plasticity and imagined materiality in colourful ashlars. The viewer of the image is thus led to believe that he or she is surrounded by sumptuous materials which constitute a 'grand' architectural space. The more perfect this illusion becomes, the more powerfully the image denies its pictoriality. ${ }^{9}$

This interweaving of architecture and sculptural wall images is particularly evident in the case of mock architecture, such as plastically modelled false doors and upper zones. ${ }^{10}$ In the atrium (A) of the Casa di C. Iulius Polybius (IX 13,1-3), a real door to the right of the tablinum corresponds to a false door on the left (Figure 1). ${ }^{11}$ Since such illusory architecture is devoid of any functionality, illusion and illusory rupture are intrinsically related to each other: ${ }^{12}$ a false door cannot be used.

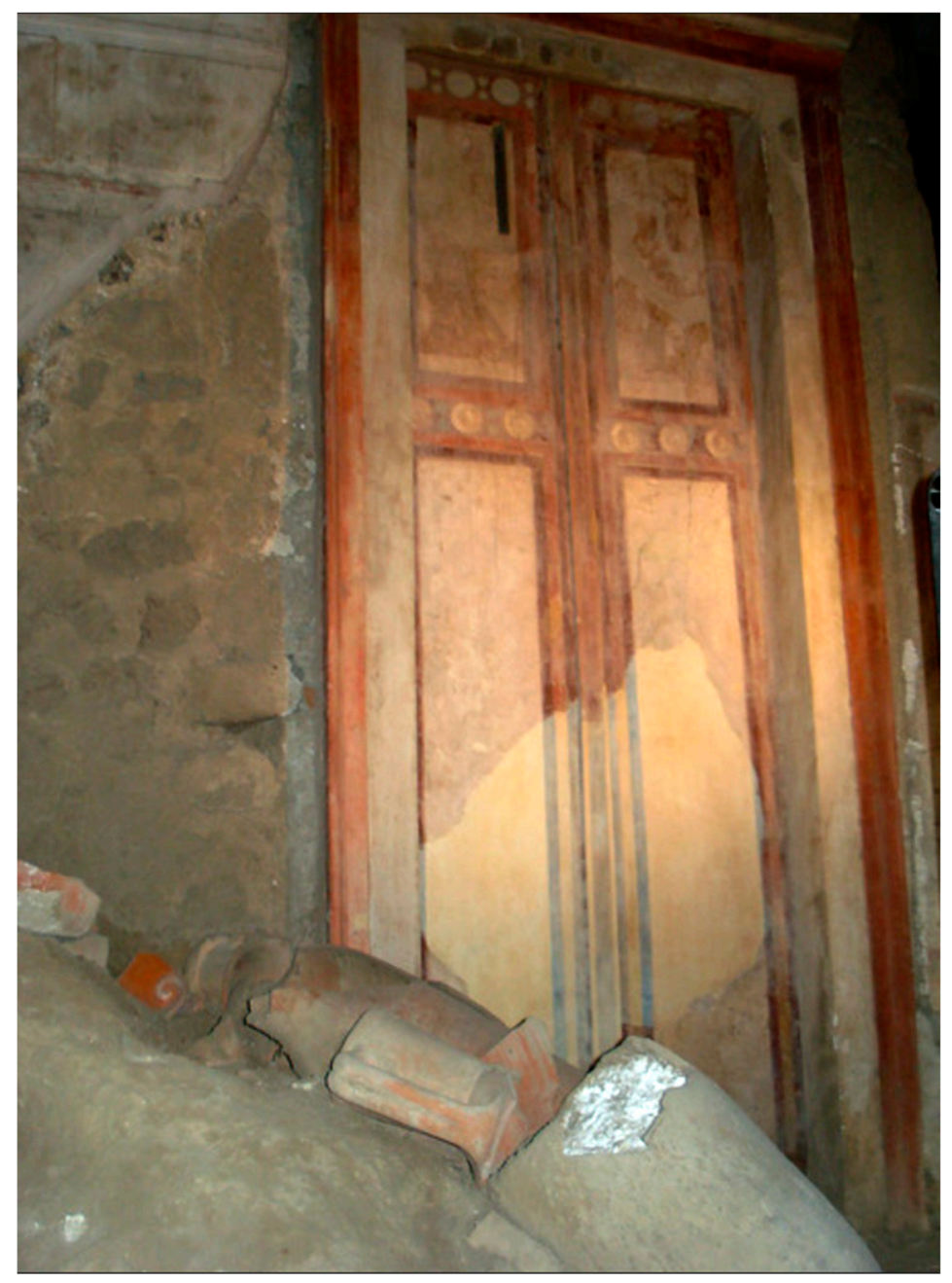

Figure 1. Casa di C. Iulius Polybius (IX 13,1-3), atrium (A), false door on the left side of the tablinum (Jashemski Archive J68f1656). 
The situation is even more complex for fictive wall structures. Various decorative elements undermine the impression that the surface is a real wall. ${ }^{13}$ The stucco 'representing' a wall can expose the wall's pictoriality. ${ }^{14}$ Stucco walls do not present orthostates in the lower zone of the wall, where such orthostates would make sense for static reasons. Instead, orthostates are moved to the middle zone of the wall as visually attractive main elements (Figure 2). ${ }^{15}$ As the middle zone is occupied by orthostates, there are very few (usually three) rows of ashlars leading up to the epistyle, whereas a real wall consists exclusively of such ashlar layers. ${ }^{16}$ In stuccoed wall construction, the lowest ashlar layer often illogically protrudes slightly. The tension between real-wall construction and wall ornamentation is particularly clear in the corners of the room. ${ }^{17}$ Here, the ashlars can be visually integrated into the wall and represent the wall structure as logically correct, such as in the ala (42) of the Casa di Sallustio (VI 2,4) (see below, Figure 6). ${ }^{18}$ Much more often, however, the corner ashlars adjoin each other as decorative surfaces, making the wall structure more ornamental, such as in the oecus (b) of the Casa di M. Epidius Sabinus (IX 1,22.29). The upper part of the wall is also treated illogically. The epistyle breaks off inorganically where it is interrupted by real room openings, such as doors. Above all, however, the epistyle does not represent the upper termination in the wall structure but instead separates the middle from the upper zone. ${ }^{19}$ The ornamental quality of the wall design becomes especially apparent in areas where different room compartments meet. In the Casa del Centauro (VI 9,3.5), the cubiculum (3) possesses an antechamber and an alcove, each with its own wall design (Figure 2). The wall design suggests a precious ashlar wall, but the breaks with the static logic of built wall indicate the stucco to be pictorial. It is a simulacrum without an original, ${ }^{20}$ i.e., without real marble walls existing as a model. It allows for a new aesthetic which is characterized by its highly ornamental character. ${ }^{21}$

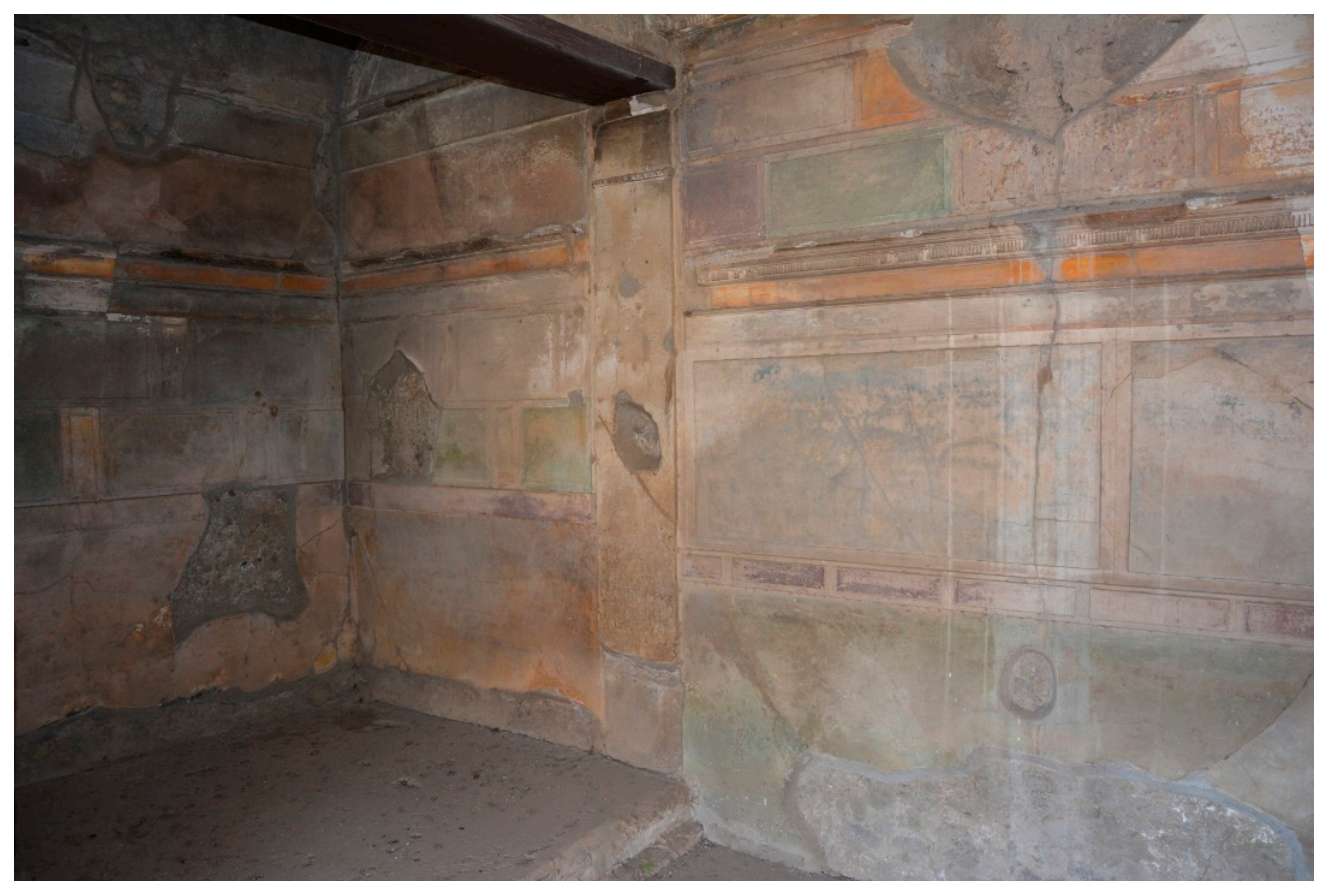

Figure 2. Casa del Centauro (VI 9,3.5), cubiculum (3), antechamber, and alcove (photo: [anonymized]).

\section{Surface Qualities: Three-Dimensionality and Colour}

With the renunciation of figural depictions, the ashlar structure, which is rhythmised by forms and colours, catches the eye. The visual pattern represents not only a (fictive) wall but also functions as an ornament of the (real) wall. Let us now consider the specific aesthetic qualities of this surface design. 
The first prominent surface quality of First Style walls is their three-dimensionality. Through this three-dimensionality, the stuccoed image of the wall gains a haptic quality and becomes more 'real'. This factor has consequences for the artificial modelling of light. In the First Style, interactions between real light and shadow on the wall were created through the sculptural differentiation of ashlar blocks by projecting courses of ashlar blocks or projecting string courses. Most importantly, these interactions were produced by stucco cornices ${ }^{22}$ which produced minimal shadows on the side facing away from the light. ${ }^{23}$ The shadow thus corresponded to the real lighting conditions used to model the wall. However, this light-shadow modelling only 'works' if the light illuminates the room relatively evenly. If a cone of light falls on a wall, the colours on that part of the wall will glisten, severely disturbing the systematic effect of the wall structure.

Only in very rare cases three-dimensional friezes were integrated into the wall-e.g., metope-triglyph friezes or rosette friezes (see below, Figure 7). ${ }^{24}$ A real light-shadow effect is also achieved through the three-dimensionality of the designed stucco surface. Rarely are light and shadow - and thus three-dimensionality — created by colours. This is especially true for painted architectural elements, such as friezes and coffered ceilings. ${ }^{25}$ The Tuscan atrium of the Protocasa del Granduca Michele (VI 5,5) possesses this type of decoration. With a painted dentil cornice and a perspective-painted coffered ceiling with a central rosette motif, illusionistic elements were introduced into the wall decor (Figure 3). Imitation using paint provided these areas with special sophistication, as lighter and darker colour values created the illusion of light and shadow.
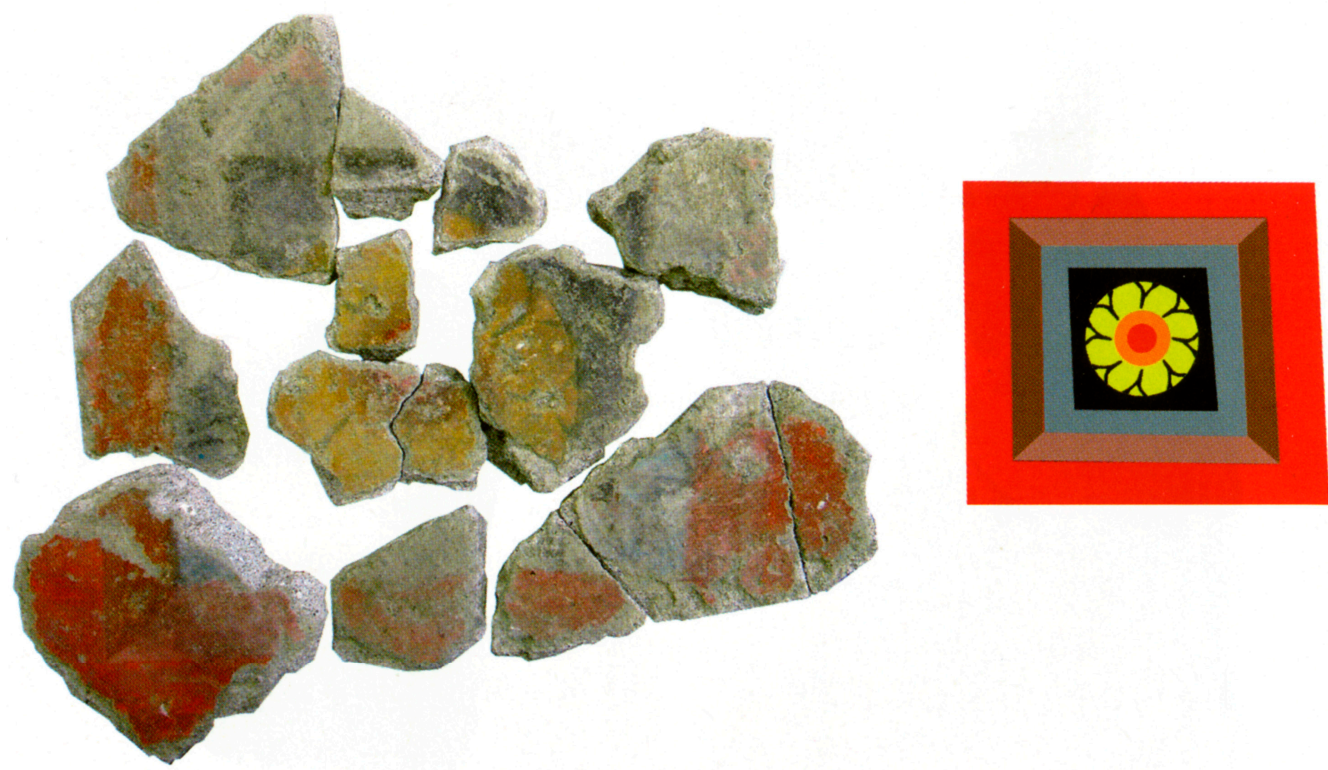

Figure 3. Protocasa del Granduca Michele (VI 5,5), fragments of a painted coffered ceiling (D'Auria 2011, Pl. 24).

The second prominent surface quality is colour. The ashlar blocks appear in bright monochrome hues-mainly purple, yellow, and green, but also black and white (see below, Figure 5). ${ }^{26}$ This monochromy dispels the illusion of a 'real' surface texture. ${ }^{27}$ This artificial effect is also observable in the case of imitated stones such as alabaster, marble, and breccia blocks. ${ }^{28}$ In principle, such imitations would seek to achieve a more realistic representation of stone. They become indicators of the transmaterial character of the whole wall design. ${ }^{29}$ However, these imitations range from naturalistic to abstract and stylised. ${ }^{30}$ The visual effect of such imitations is not to 'deceive' the viewer but to animate the wall surface. This factor becomes especially clear in the case of the abstract imitations, which develop an ornamental life of their own (see below, Figure 9). In the fauces of the Casa del Fauno (VI 12,2.5), the irregular stone structure including molluscs and marine fossils form a clearly 
intentional contrast to the geometric, rectangular structure of the wall construction and thus enliven the wall zone (Figure 4, cf. also Figure 9). ${ }^{31}$ The fact that marble and breccia were imitated can thus be explained by their ornamental surface structures. Transmateriality enters the service of the ornamental. Vice versa, as Seneca, Statius and Martial attest, real marble surfaces were also appreciated for their pictorial qualities. ${ }^{32}$ The imitation of marble by colour thus allows for sophisticated intermedial play with ornamental qualities. Here, the ornamental effect increases as the colour scheme from one block to another becomes inverted. ${ }^{33}$ Obviously, the rhythmised orthostatic and ashlar colours contribute to an ornamentalisation of the wall. ${ }^{34}$ The 'unreal', ornamental effect becomes even more evident when the ashlar block and its drafted edges differ in colour. Colour, then, plays a purely ornamental role. This is also true for ornamental colour patterns such as lozenge patterns which do not correlate with the ashlars of the wall and are therefore not related to the architectural image. They usually animate the socle zones of prominent rooms-e.g., in the fauces of the Casa del Fauno (VI 12,2.5). ${ }^{35}$

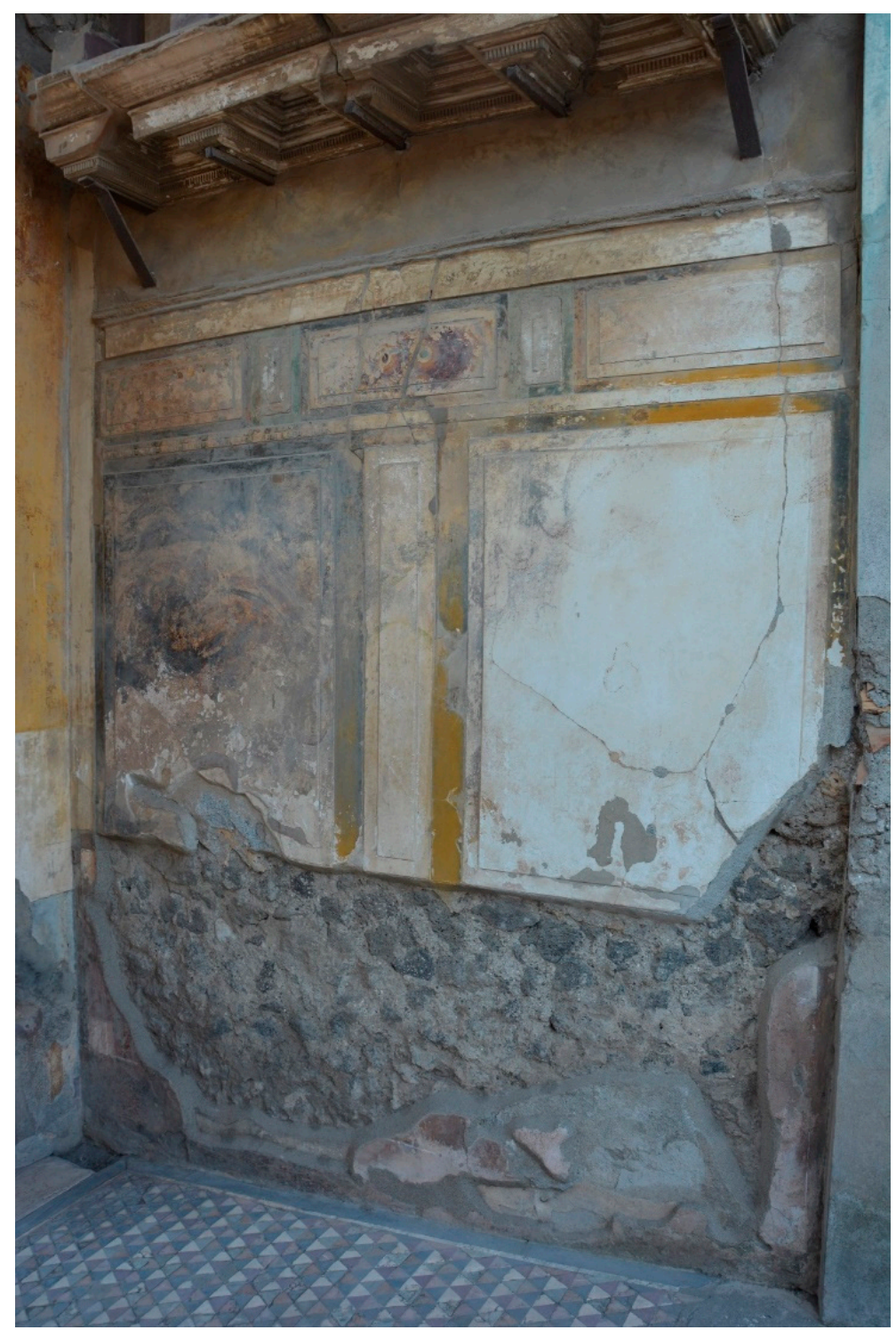

Figure 4. Casa del Fauno (VI 12), view from the western atrium toward the western wall of the fauces (7/53) (photo: Julika Steglich).

The ornamental effect becomes most clear in the colour design of the entire wall. Ashlar blocks of the same colour are never placed next to each other. ${ }^{36}$ Instead, the placement of 
colours produces a rhythmic, visual effect. ${ }^{37}$ Moreover, the colour patterns help separate individual wall zones from each other or even create attractive patterns within a single zone ${ }^{38}$ Larger parts of the room can also be related to each other in this way. This principle is confirmed by the Casa di Sallustio (VI 2,4). Here, the atrium and alae (Figures 5 and 6) have the same structure with a red plinth, yellow base, and black orthostatic zone, but the zones are slightly offset in height..$^{39}$ In the atrium, a purple fascia follows above; in the alae this is a cornice. Above all, the adjoining rows of ashlars differ. In the atrium, red and yellow panels alternate in the lowest row of ashlars, yellow and violet and yellow and red ashlars alternate in the second row, and dark and light ashlars alternate in the third row. The wall then ends with a large yellow panel, violet fascia, and kyma. The alae feature only two rows of ashlars, with marbled ashlars alternating in yellow, red, and purple; above, a large yellow panel, fascia, and kyma are adjoined. In the tablinum (19), a white plinth is followed by a yellow pedestal, which here is more concise, finishing at the same level as the atrium pedestal. Above the tablinum are large framed horizontal orthostates (also black), followed by a belt; two rows of ashlars with alternating colours of violet, yellow, green, and red; and various marbles. A projecting purple belt with a garland painted in white is located at the level of the dentil cornice of the atrium (see below, Figure 8). The subsequent row of panels in purple and imitation marbles is bordered by a fascia, and the wall terminates with the kyma. These small-scale observations show how individual wall zones are joined or separated by the wall decor, as well as how the wall decor assumes the function of creating visual ensembles or marking independent sections of the room. Surface design thus provides visual orientation within spaces.

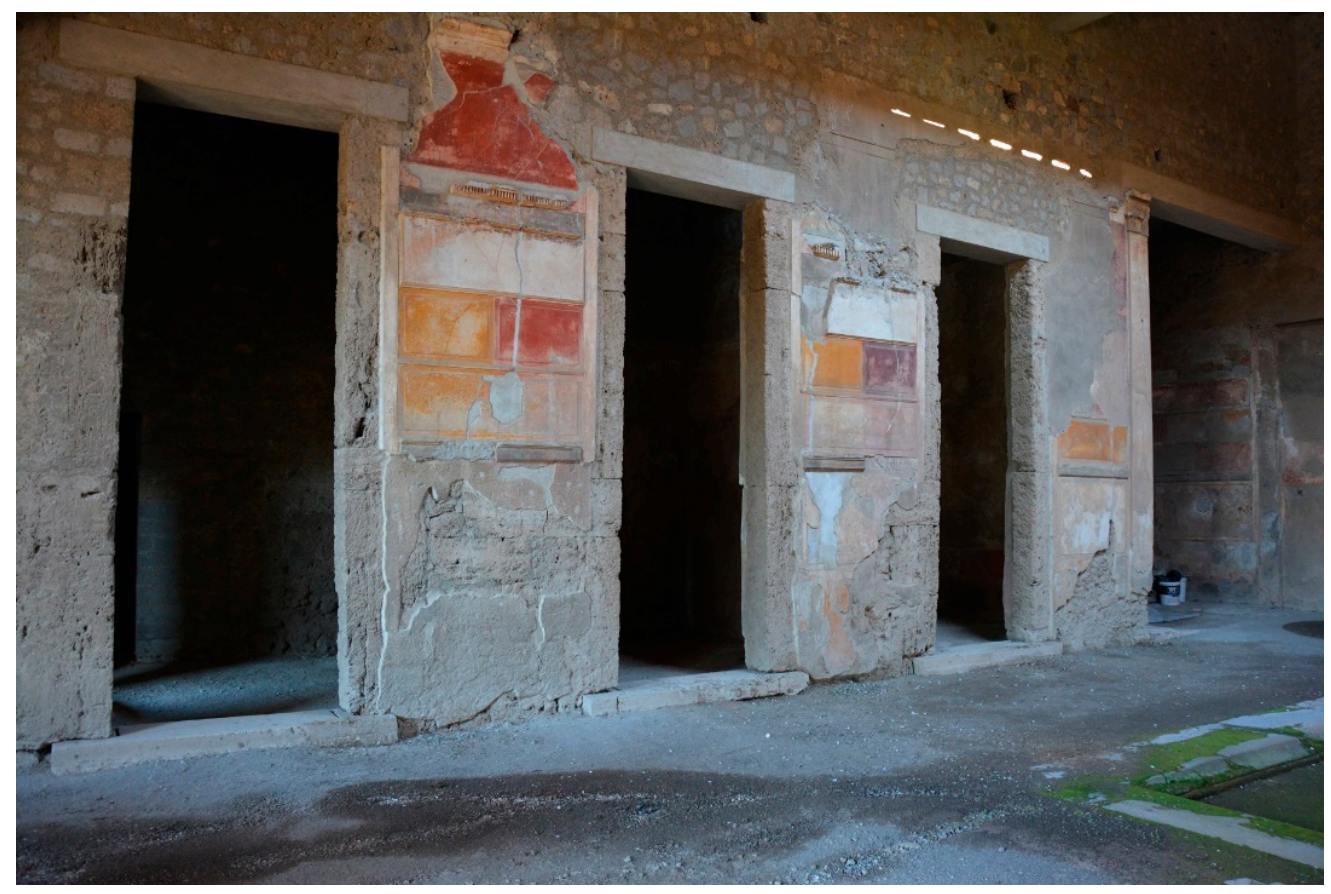

Figure 5. Casa di Sallustio (VI 2,4), atrium north wall (photo: [anonymized]). 


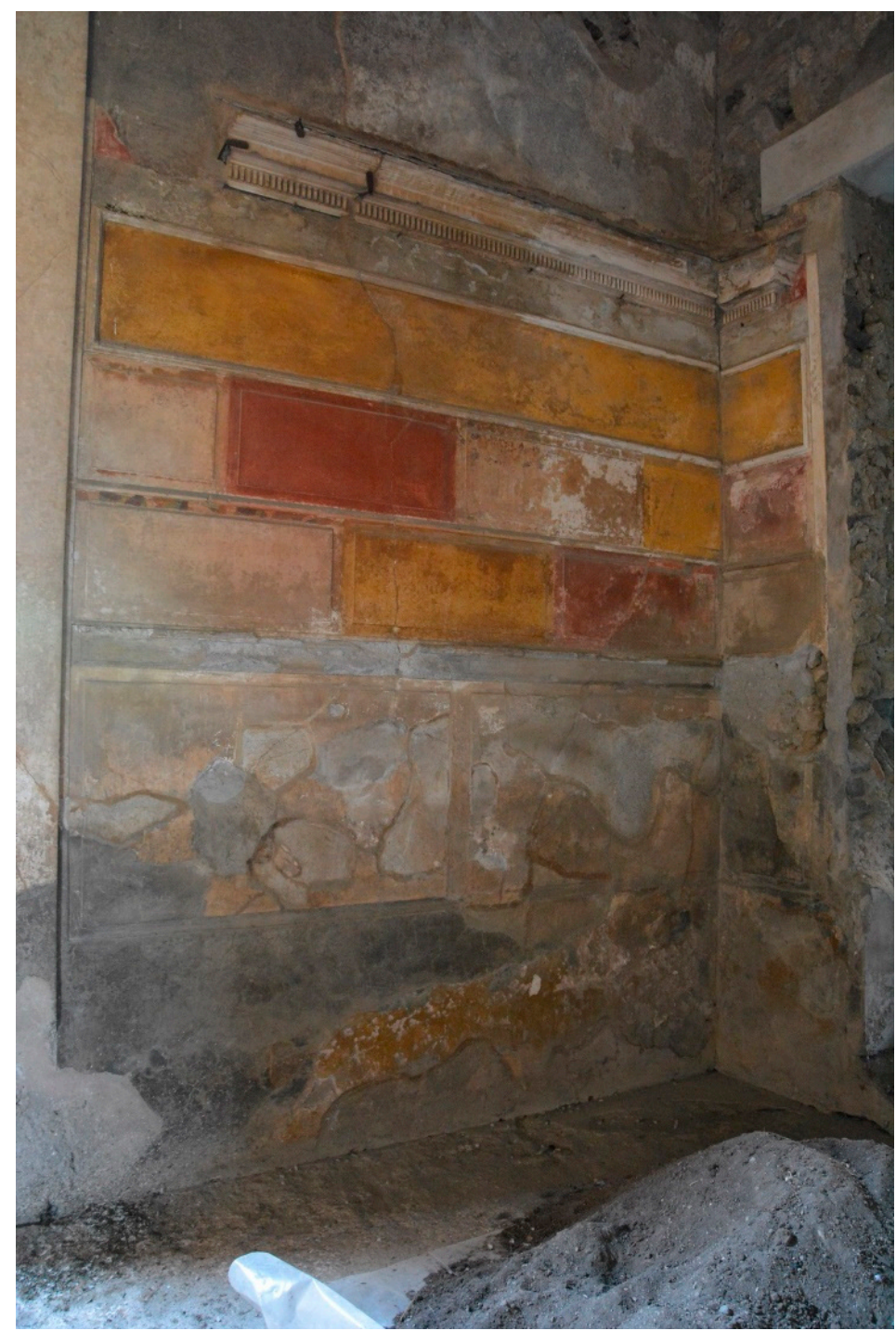

Figure 6. Casa di Sallustio (VI 2,4), ala (42) (photo: [anonymized]).

\section{Surfaces and Images}

Generally, walls are characterised by a widespread absence of representational depictions, allowing one to speak of an 'ornamental mode' of wall decoration. ${ }^{40}$ The main interest of viewers in antiquity was likely the aesthetic appearance of the rooms, i.e., their form and materiality. When pictures did find their way into this logic of wall design, ${ }^{41}$ they occupied a transitional position. Friezes are found in the zone between the orthostates and ashlar masonry, as well as below the epistyle. In all cases, such friezes introduce further aesthetic and semantic differentiations of the surface. As particularly dense semantic elements, these friezes attract the viewer's attention. ${ }^{42}$

This phenomenon is most evident in the case of plastically modelled, three-dimensional and thus sculptural images. To date, such images are only known from outside of Pompeii. In the Campanian city of Cales, sculpted herms and stucco heads have been discovered that could belong to the First Style. In this case, these objects must have been anchored in the wall, allowing the wall to become a support and carrier for the sculpture. ${ }^{43}$ At the same time, the images gradually reach out into the space that they share with the users of the real space.

In Pompeii (as in many other places), we find stuccoed friezes realized in high relief. In the cubiculum (6) of the Casa della nave Europa (I 15,1.3) (Figure 7) the stucco rosettes introduce a distinction between the foreground and background. The same holds true 
for Doric friezes, such as the one in the atrium of domus I 8,18; such friezes represent a visual element of stone architecture. ${ }^{44}$ Their semantic strength remains relatively weak. As plastic architectural friezes they fit seamlessly into the architectural image of the overall wall, belonging to the same media space.

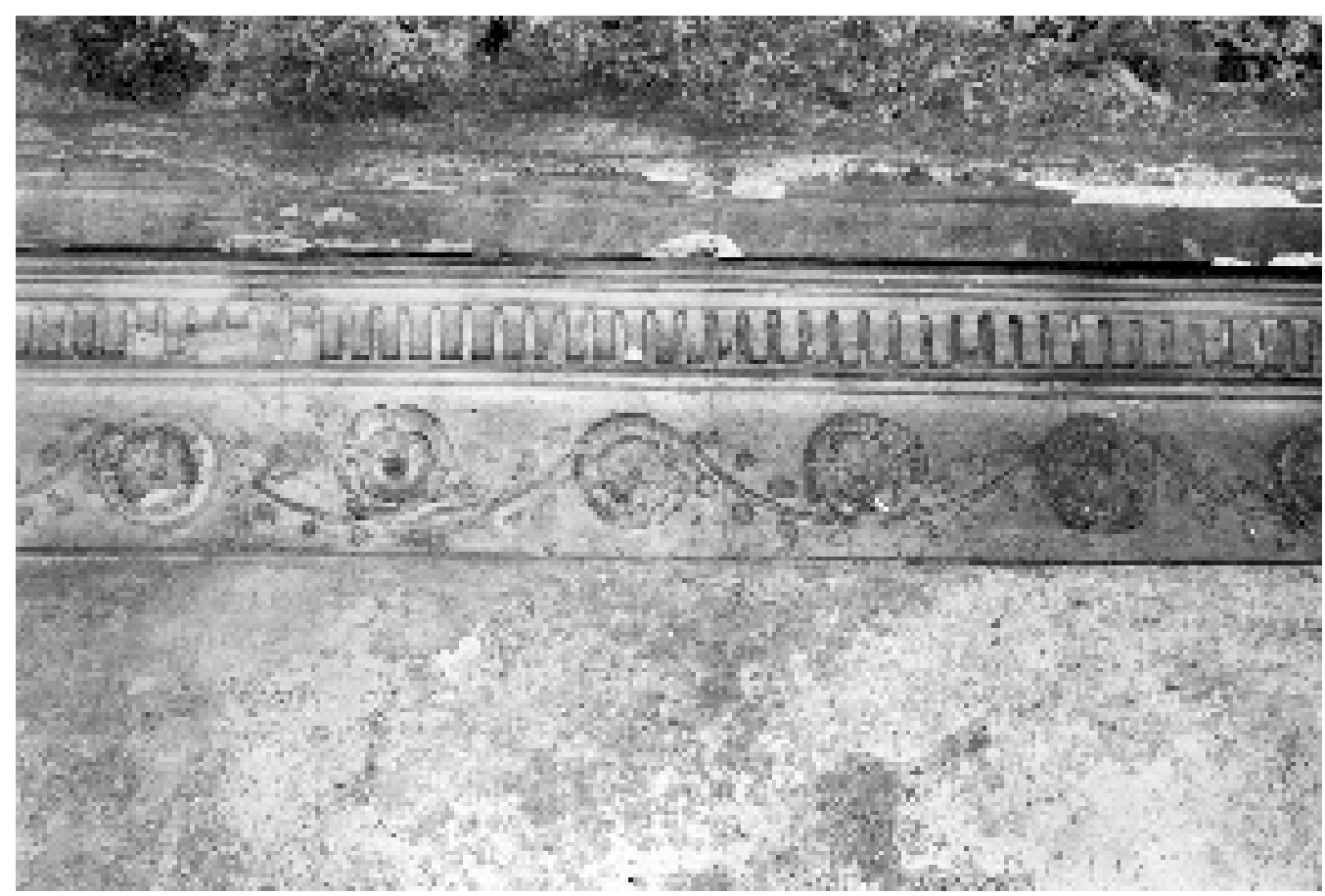

Figure 7. Casa della nave Europa (I 15,1.3), cubiculum (6), plastic rosette frieze (American Academy in Rome, Photographic Archive: Laidlaw.P.72.17.16).

The same applies to painted friezes: they fill a plastically modeled frieze zone, which thus logically relates to the architectural wall image. However, by refraining from a plastic representation, the play with foreground and background (and the notion of depth) is translated into the two-dimensional medium of painting. In the Casa di Sallustio (VI 2,4), the painted frieze found in the tablinum (19) (Figure 8) is a vegetal vine frieze that represents nature but lacks any narrative density. Here, again, the friezes oscillate between image and ornament.

In other houses of the period, however, iconographically denser subjects are known. From the Casa del Naviglio (VI 10,11), fragments of a yellow-ground frieze zone with bird representations are known from the area of oecus (16), which the excavators dated to the third century BCE (Figure 9). ${ }^{45}$ Elsewhere, we find equestrian friezes. ${ }^{46}$ In these cases, there is more at stake than a differentiation of the surface into figure and ground. These semantically denser representations introduce an expansion of semantic space. In this way, the stuccoed wall and its painted images are no longer merely an ornamental-pictorial space surrounding the viewer but become the carriers of independent images. In the Casa del Naviglio (Figure 9), the bird's feet transgress the plastic 'frame' of the frieze zone (Figure 9). The illusion of a frieze zone is thus disturbed. The pictorial quality of the image is further enhanced by the rich colours in which the bird is rendered. These colours clearly stand out against the brownish marble imitation of the background. There is also sophisticated play with the foreground and background. The brown branch pecked by the bird interferes with the surface pattern and imagined stone surface of the background. Here, different pictorial levels, each correlating with different imagined materialities, compete with each other and therefore playfully blend previously distinct material categories. 


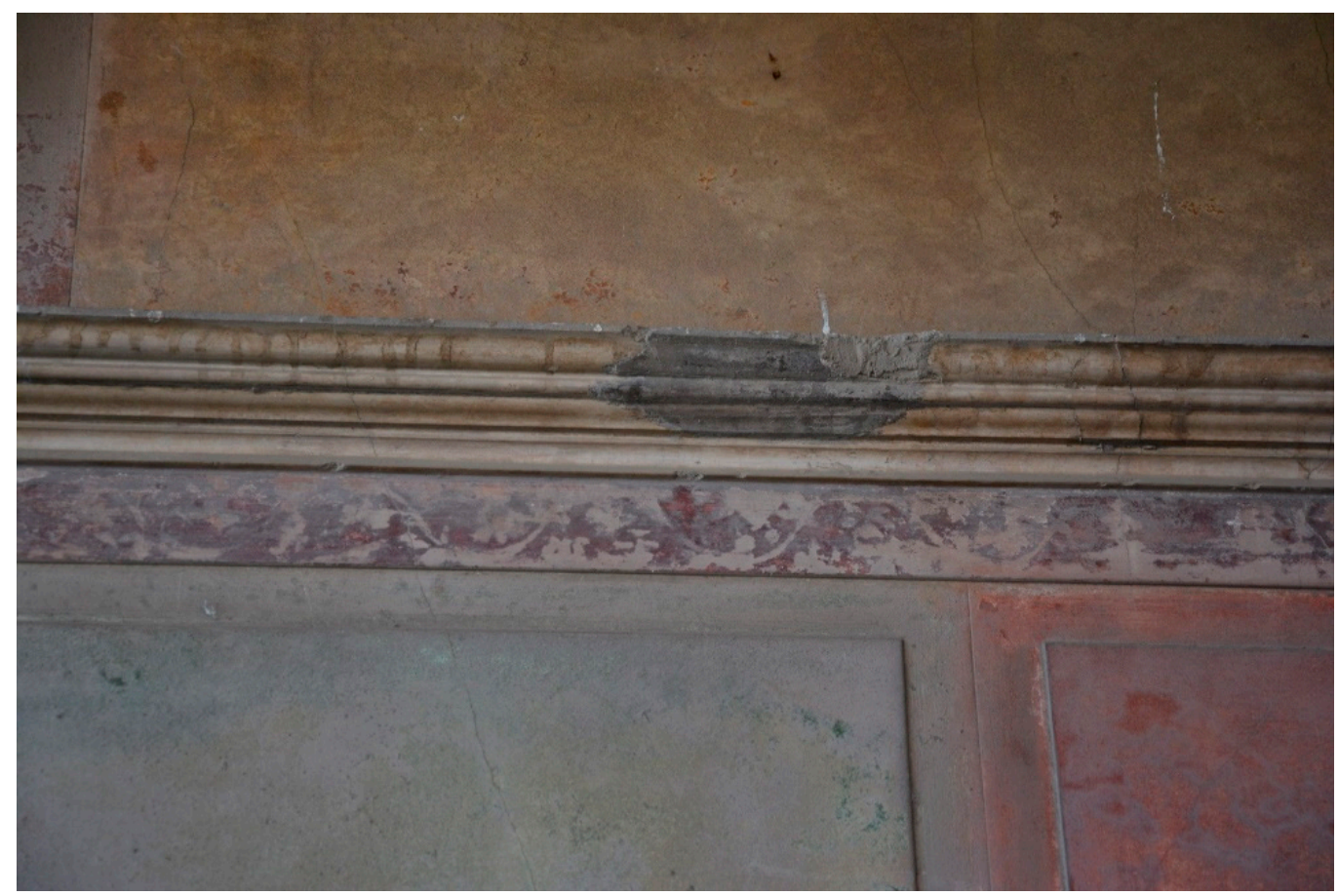

Figure 8. Casa di Sallustio (VI 2,4), tablinum (19), garland frieze (photo: [anonymized]).

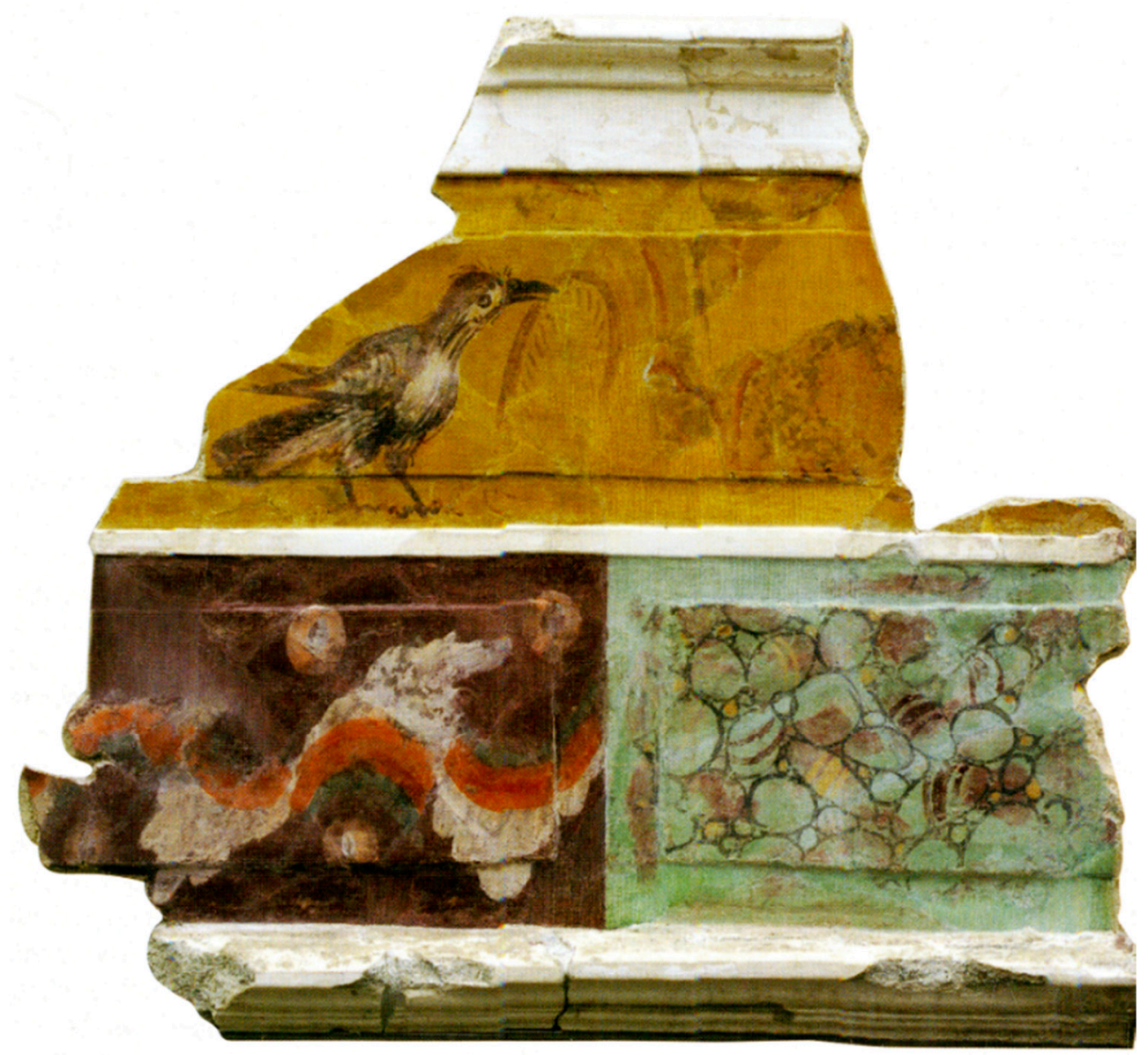

Figure 9. Casa del Naviglio (VI 10,11), oecus (16), depiction of a bird (Pesando 2008, p. 167 Figure 9).

This tension between stuccoed architectural images and figural images is even stronger when the surface of the stuccoed blocks becomes the carrier of a painted image. The 
ornamental stucco ashlar thus becomes the 'background' of the image. Usually, the images are given as monochromata, for which two forms of pictorial realisation can be distinguished. When monochrome ashlars form the background, the slightly darker tone of the line colour stands out against the colour of the ashlar surface. When the stuccoed ashlars possess a marbled surface, a figural image is 'drawn' into the marble veins. ${ }^{47}$ Let us consider one such example in greater detail.

In the oecus (b1) of the Casa di M. Epidius Sabinus (IX 1,22.29), which opens into the peristyle (Figure 10), several figural monochromata in red-brown and beige tones have been preserved. ${ }^{48}$ These monochromata all appear in one row of ashlar blocks. Here, the very narrow headers function as picture supports, the ashlar drafts work as picture frames. The west wall portrays a muse with a lyre and a dancing satyr. The north wall, opposite to the entrance, depicts a seated female figure with a small vessel in her right hand, a standing male figure with a sword, a female figure with a long robe, and a female figure shown in three-quarter view. Here, action is completely withdrawn, as the ashlars each show individual figures. ${ }^{49}$ The alternation between images and marbled stretchers creates a regular rhythm, reminiscent of a Doric frieze. The images are presented casually, subordinate to the architectural wall structure-an impression that may have been reinforced by their monochromy. However, by using individual ashlars as image carriers, the illusion of a 'real' wall structure is broken by a contrary (meta-)illusion ${ }^{50}$. The images call into question the solidity of the wall, as the pictorial spaces introduce imaginary, fictive transparency into the wall system. Due to the reduction in the colour spectrum of the figural representation, the painted image acquires the qualities of a relief. First Style images thus introduce play with different materials and media (remediation) ${ }^{51}$ through transparency and opacity. ${ }^{52}$ Here, the presence of one medium begins to fade as soon as that medium starts to engage with the represented medium. ${ }^{53}$

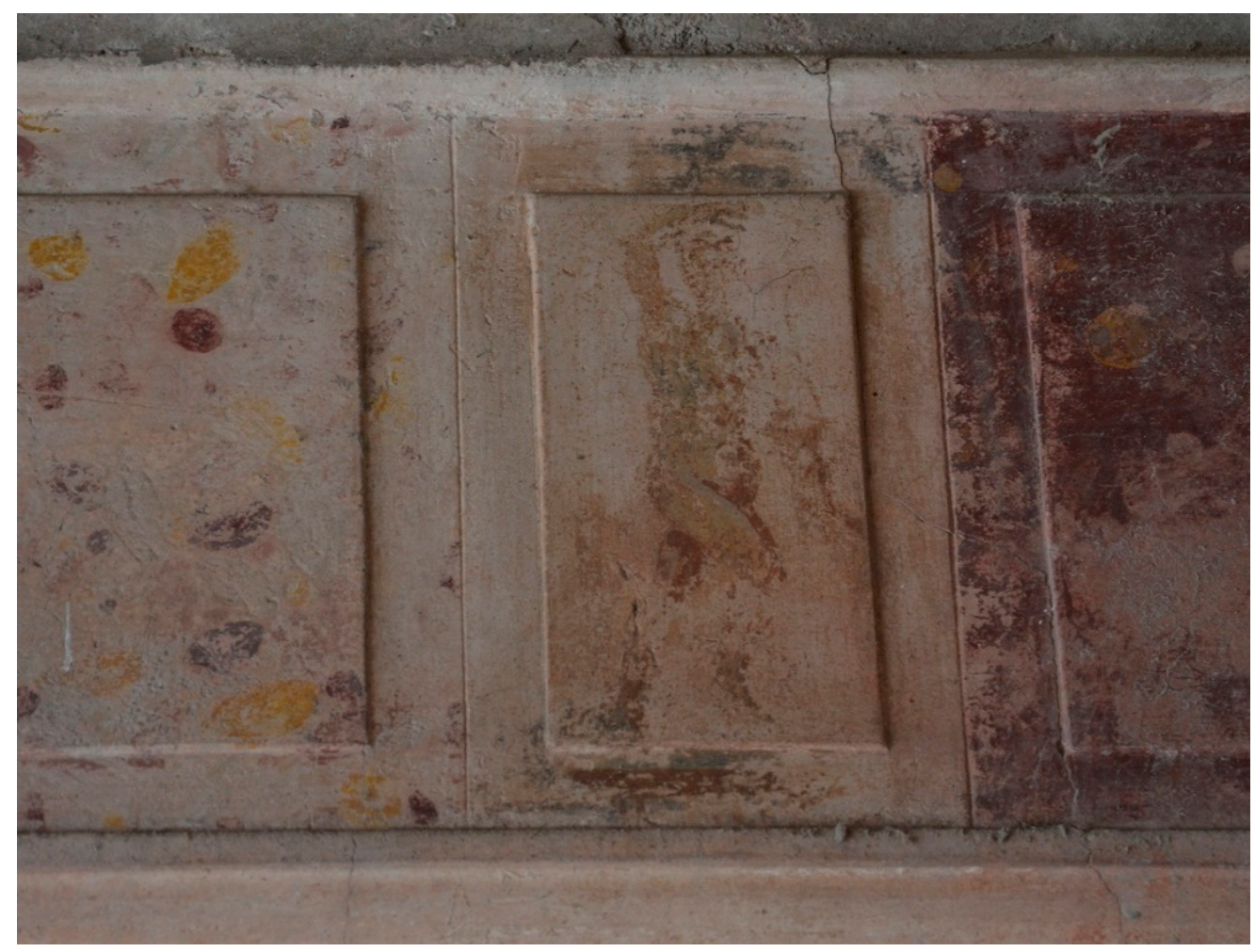

Figure 10. Casa di M. Epidius Sabinus (IX 1,22.29), oecus (b1) with a figural representation on the ashlar zone (photo: [anonymized]). 


\section{Surface and Physical Space: Symmetry/Axiality, Multiplication of Architectural Elements, and Scale}

At the beginning of this article, surfaces were introduced as interfaces. Indeed, wall surfaces are characterized as interfaces because they are related to the physical-architectural space and also, therefore, to the human actor moving in that space.

One dimension of interdependency between surface and space is the adherence of the decoration to specific principles of order. Architectural space is an ordered space. As Roman architecture essentially resorts to rectangular spatial structures, its basic modules (rooms) are already symmetrical. The principles of symmetry and axiality, however, also determine the layout of entire buildings-e.g., houses, such as the Casa del Fauno, and public buildings, such as the Sanctuary of Apollo. However, to what extent do the surfaces of a room reinforce or undermine this spatial order? Wall design may provide an answer. Orthostates and ashlars create a paratactic sequence and emphasise the horizontal orientation. Consequently, early rooms lack any axially organised decoration. Axiality is also dispensed with in favour of parataxis in the peristyles, where a vertical element is present in the form of pilasters on the outer courtyard walls. Thus, it is only singular contexts such as the fauces of the Casa del Fauno (VI 12) that experiment with axiality (see above, Figure 4). Here, the central wall section consists of three orthostates: Two wide orthostates imitating marble flank and a narrow orthostat imitating light alabaster. ${ }^{54}$ Although this arrangement creates an axial structure, unlike in the Second and Third Style, the centre of the wall is not emphasised by a particularly prominent element but is instead recessed by the narrow orthostat, which acts as a separating pilaster strip. For those who walk through the fauces, it is not so much axiality but a regular rhythm that is experienced. Symmetry and axiality thus represent an architectural principle of order that decoration is able to refer to or explicitly avoid. In the case of the First Style, the decoration focuses more on achieving horizontal order than additional vertical structuring and axiality.

The wall design can make reference to the surrounding built space in a much more explicit way by the multiplication of architectural elements. False doors (see above, Figure 1) or false upper floors constitute such features. Even more sophisticated is the design of First Style peristyles. Pilasters on the peristyle rear walls not only structure the walls but also correspond to the three-dimensional columns. In some cases, the stuccoed ashlar blocks continue 'behind' the pilasters and evoke a sense of depth. A particularly sophisticated use of depth was achieved in the three-sided peristyle of the Casa dei Capitelli figurati (VII 4,57) (Figure 11). Here, Ionic half-columns built from masonry are set in front of the western rear wall of the peristyle ( $t$ ). These half-columns correspond to the opposite full Ionic columns and thus create the illusion that the portico continues on this side. ${ }^{55}$ This illusionary and immersive effect is further enhanced by the subdivision of the wall between the Ionic half-columns by flat Doric stucco pilasters. One pilaster bisects each intercolumnium, while half pilasters adjoin the half columns on either side. The pilasters support a cornice followed by three rows of stuccoed ashlars and an epistyle. This gives the impression that a portico runs behind the half-columns (imagined as portico columns) and that one is looking at the back wall of the portico, divided by pilasters. This staggering of different levels increases the depth of the space. The wall design is directly related to the spatial experience of the peristyle. However, the wall closes behind the pilasters of the peristyle and behind the false architecture of the upper floor zones. Each room and the house as a whole are enclosed on all sides by solid, closed walls. Additionally, this visual concept refers again to the primary architectural situation: the house as an enclosed space. 


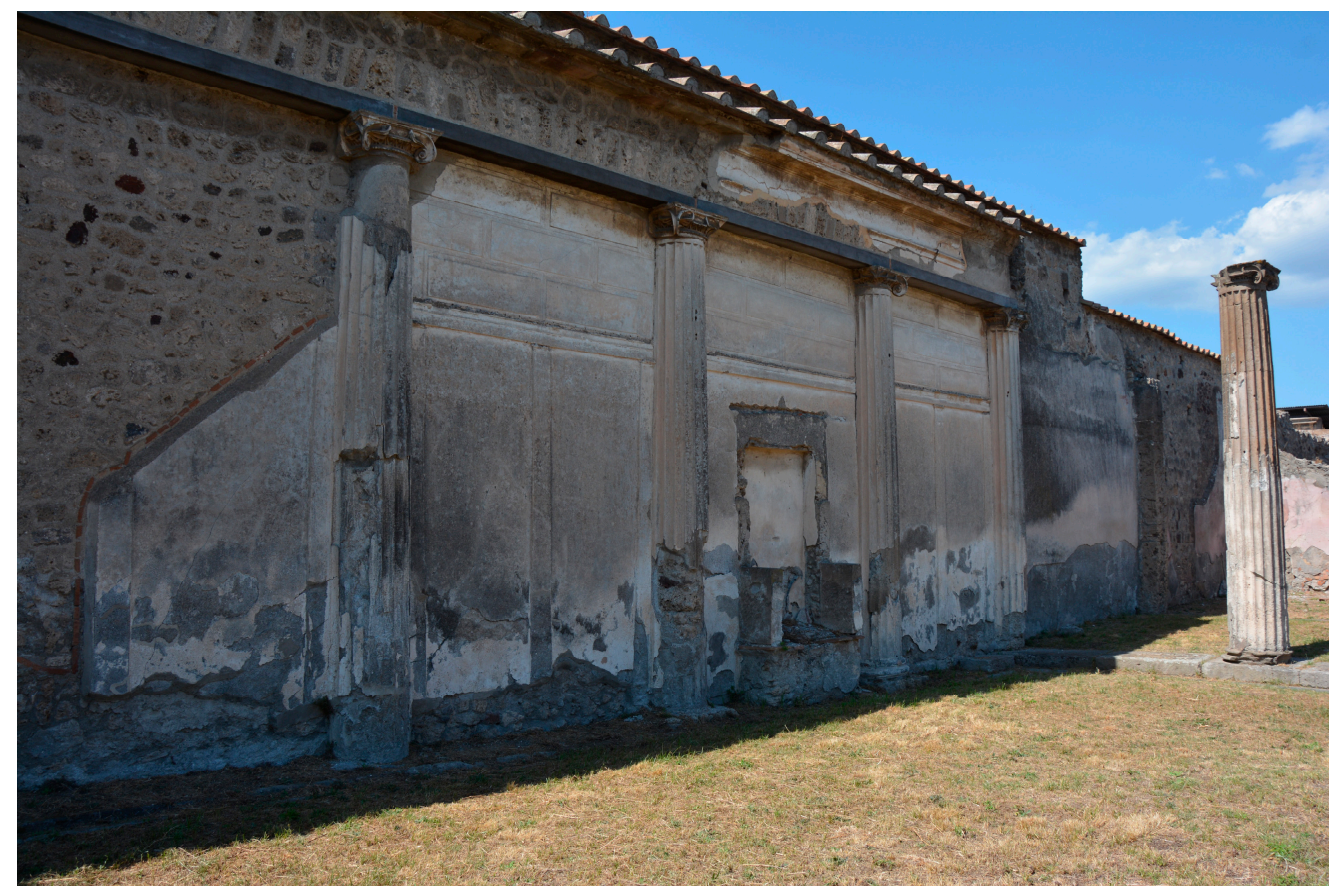

Figure 11. Casa dei Capitelli figurati (VII 4,57), back wall of peristyle (t) (photo: [anonymized]).

Not only the visual form, but also the scale of the wall design hints at the physical space. Decor scale in early houses depends on the volume of the room. In large courtyard areas, the absolute sizes of orthostates and ashlars are considerably larger than those in small rooms. This change in decor scales becomes immediately apparent in the Casa del Labirinto's (VI 11,8-10) cubiculum (24), with its small First Style ashlars (L: $54.4 \mathrm{~cm}$; W: ca. $20 \mathrm{~cm}$ ) passing through the doorway into the eastern atrium with its large ashlars (L: $100 \mathrm{~cm} ; \mathrm{W}: 36 \mathrm{~cm})^{56}$. In the Casa del Fauno (IV 12,2.5), such a contrast can be observed in the northern peristyle. Here, the showcase niche $(34 / 50)$ is offset against the rear walls of the courtyard (Figure 12). In cubicula with antechamber and alcove, a comparable principle of size differentiation is expressed (see above, Figure 2). ${ }^{57}$ The size of the decoration as perceived by the viewer is produced, on the one hand, by the visualised ashlar sizes and, on the other hand, from the distance between the viewer and the wall. The ashlar blocks in small rooms that are seen from nearby are perceived as small, while the ashlar blocks of large atriums are perceived as large. As a consequence, the intimacy of small rooms intensifies, as does the grandeur of large rooms. Rooms are thus provided with an atmosphere through the scale of their decoration. At the same time, this phenomenon suggests a viewer-dependent perspective on the wall. Thus, the First Style stimulates certain viewer perspectives. Unlike the Second Style, however, this perception was (mostly) not achieved through illusionistic architectural painting but instead by scaling the sizes of decoration. Accordingly, light and shadow are not created by painting but by the real lighting conditions (see above), making large rooms seem more spacious and small rooms more intimate. ${ }^{58}$ 


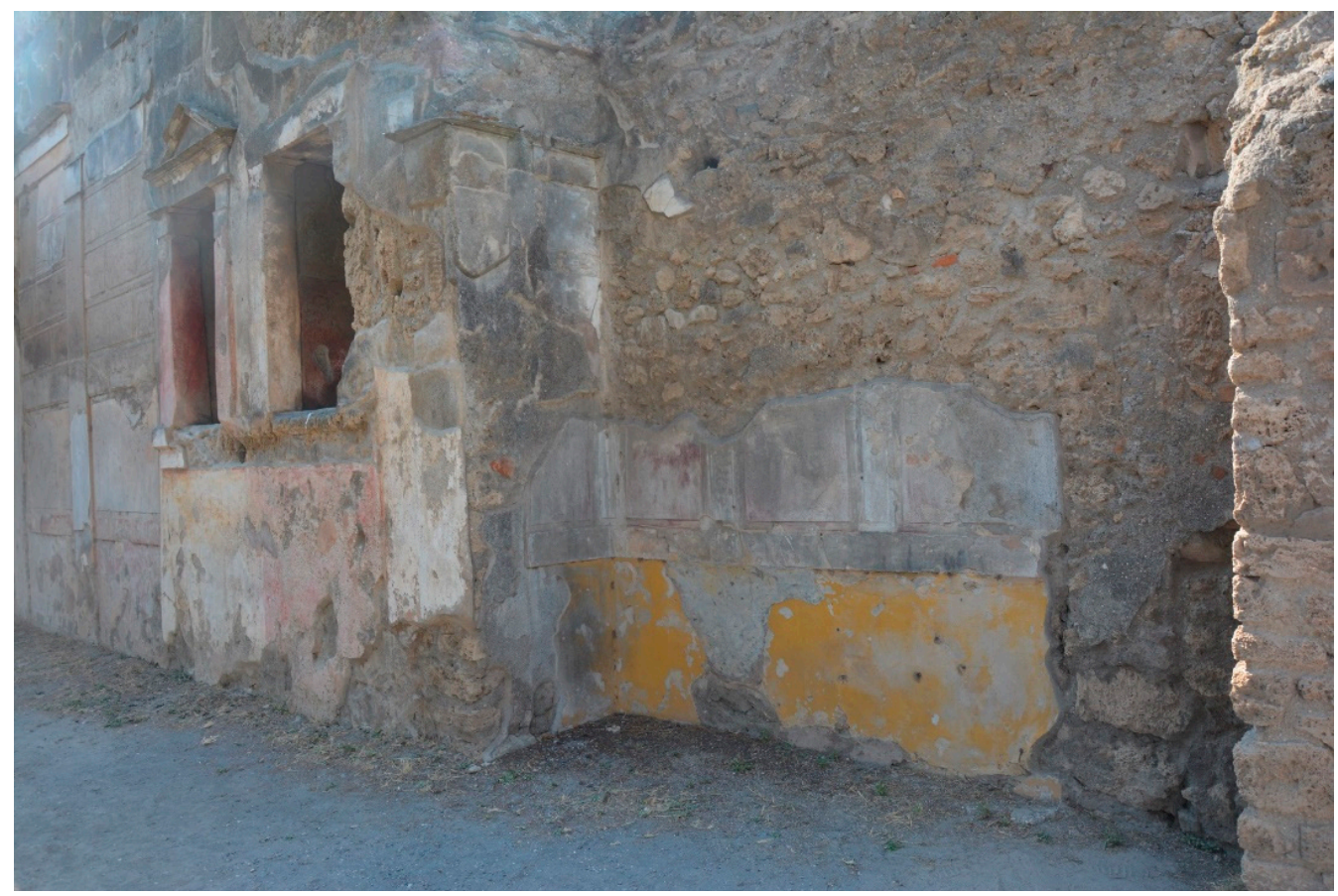

Figure 12. Casa del Fauno (VI 12), niche (34) with small-scale decoration (photo: [anonymized]).

\section{Surface and Social Space: Light and Richness of Details}

Surfaces are not only related to the architectural features of the physical space but also to its social qualities. The social connotation of a space arises from its factual use, traditional concepts of use, the architectural design but also the decorative quality and density of said design. In the following, two prominent aspects of the interdependency of surfaces and social space are addressed.

Light constitutes a central feature that models surfaces. In the atrium house-a prominent architectural house type during the First Style-the architectural design of (day)light reflects structures of social use. The houses of the second century BCE were characterised by bright courtyards. The large peristyle courtyards, in particular, were flooded with light, ${ }^{59}$ the semi-dark atriums were lit by the compluvium; and when the door was opened, light from the fauces was introduced in addition to light from the rear tablinum window. ${ }^{60}$ With the tablinum, the atrium was a relatively bright room. The alae without their own light sources were somewhat darker, while the high cubicula were illuminated only by small slits of light, if at all. ${ }^{61}$ Large triclinia are, therefore, often placed between the atrium and the peristyle or directly at the peristyle to provide large windows with a garden view, as well as additional brightness. The distribution of light not only suggests certain ways of using rooms but also has a direct influence on the perception of surfaces. In the brighter rooms alone, daylight models the surfaces and allows for their detailed observation. The factor of 'light' thus represents per se an architectural design quality that contributed to the social hierarchization of spaces.

The social value of surfaces is not only a result of their lighting and visibility, but also of their design. Social value is expressed by the richness of details, such as the interplay of small-scale and large-scale forms, monochromy and polychromy, ornamentation, and imagery. The targeted use of decorative efforts can already be seen in the structure of the wall itself. The plinth zones remain (mostly) undifferentiated, as does the wall section above the epistyle. ${ }^{62}$ The design focuses on the zones starting at the upper-body height of the standing viewer and reaching up to slightly above head height (the passage height of the doors). Within this central zone, large areas that calm the wall (orthostates and rows of ashlars) $)^{63}$ alternate with small-scale zones of transition (string courses, fasciae, kyma reversa, etc.). ${ }^{64}$ These transition zones are already small-scale, per se, but can be further 
differentiated. Perspective meanders and garland friezes frequently occur in such 'frieze zones'. ${ }^{65}$ Where figurative representations were introduced on ashlars, they often appear on the first, small-scale, and plastically protruding row of ashlars in a room. ${ }^{66}$ While the large surfaces provide calm and coherence to the room, the small areas entertain the eye. The use of colour intensifies this effect. The plinth zones remain (mostly) monochrome, while the socles-only in especially elaborate rooms-are used as carriers of differentiated decor (e.g., curtains or lozenge patterns). Large lying orthostates are often black and thus completely withdrawn in their colourfulness. Beyond the individual walls, polychromy and richness of detail are design features that allow rooms to be occupied with varying degrees of effort and different atmospheres. ${ }^{67}$ They can be found in bright atria and triclinia, but also in dark cubicula. Thus, the visual differentiation of the wall represents a form of spatial nobilisation that does not react to the lighting of a room. However, courtyards and splendid triclinia almost universally possess a relatively 'rich' decoration, while this applies only to individual cubicula of a house. Consequently, wall design does not completely invert the social spatial order given by architecture and lighting. Much more often, instead, it supports the architectural (and light) order of a building.

\section{Conclusions}

The media qualities of the First Style are summarized with regard to three categories that have been intrinsic in the preceding sections: the medium's ornamental, pictorial and spatial qualities. Each of these qualities relates the wall in a specific way to the viewer's perception.

First and foremost, the First Style proves to be an ornamental mode of wall decoration. Its ornamental quality results from the reduction of the 'wall image' to geometric (architectural) and thus non-figurative formal elements, ${ }^{68}$ their patterned arrangement, the paratactic decorative order, the repetitive colour patterns, the imitation of precious stones and, last but not least, the light-shadow effects created by the plasticity of the ashlars. This wall design invites the viewer to 'remain on the surface' and to engage with its aesthetic appearance. The medium itself gains a high presence in the perceptual process (seeing-as). ${ }^{69}$

It is the pictorial character of the First Style which introduces an ambiguity of surface perception. We can distinguish 'images' of different semantic density and different media qualities. First, the way the luxurious ashlar wall is realized in stucco. As the image of a wall is physically linked to a real wall, it invites immersion..$^{70}$ The plastic and thus haptic quality of the ashlars, the 'representation' of false doors, plastically modelled upper zones and stuccoed plastic friezes further enhance such an immersive perception (seeing-in). The stronger the effect of immersion into the virtual (and at the same time, real) 3D space, the more the mediality and pictoriality of the stucco surface fade. ${ }^{71}$ The iconic difference that makes an image distinct from reality is weak. ${ }^{72}$ However, the effects of immersion into an architectural luxury space are undermined by different visual strategies: the illogical structure of the wall as well as the introduction of painted images that use ashlars as image carriers. These strategies really expose the pictorial—and thus also media—character of the stucco wall. We thus see that the architectural image realized in stucco in turn becomes the carrier of 'images' that stabilize it (plastic friezes) or destabilize it (painted friezes and images). Let us therefore take a closer look at these two media. The plastically modelled friezes fit into the wall image-on the one hand medially, because they are realized in stucco like the ashlar wall itself, and on the other hand architecturally and logically, because they are placed where one might expect a frieze zone on a real building. Additionally, yet they create a semantic surplus-even with purely vegetal contents. When this picture within a picture invites the viewer to a more intense contemplation, the overall visual context of the wall is lost. The immersion in the frieze 'picture' is then at the expense of the overall perception of the wall. In the case of the sculpturally modelled friezes, this perception is likely to have occurred only in special cases. However, such an immersion in the picture is much more likely for painted representations-friezes and images. Already 
their media quality, but above all their (usually) higher semantic density, set them apart from the stuccoed wall image. While painted, especially figurative frieze zones fit the architectural logic of the wall but provide a semantic surplus, the use of plastered ashlar blocks as the pictorial ground questions it. The images thus invite a different form of immersion (and immediacy): immersion into the image within the architectural image. The real 3D rooms of the second century BCE thus possess surfaces that work as hypermediate interfaces. The stucco surfaces then oscillate between transparency and opacity. ${ }^{73}$

Last but not least, the wall design always has a spatial character. It relates to the space of the viewer and thus opens up a third dimension. On a basal level, this relation becomes concrete in the adoption of principles of order (such as symmetry) and scalingboth are qualities of the wall design as well as qualities of the surrounding physical space. Wall design thus orients the viewer and user of the space. On a conceptual level colours and decorative 'density' relate to the social space: the social connotation and practical social use of a specific room. Through this spatial-ambient relationship, the wall design contributes greatly to the atmosphere of a room: Surfaces become carriers and generators of atmosphere.

In sum: Ornamental qualities of wall design contribute to an intensified perception of surfaces, pictorial qualities introduce a complex play with transparency and opacity, while spatial qualities contribute to the transgression of the medium, its opening into space and towards the viewer. In all three aspects, however, surfaces prove to be mediating, media interfaces.

Funding: This research was partially funded by ERC Consolidator Grant DECOR, grant number 681269.

Data Availability Statement: The present thoughts are elaborated in more detail in Haug (2020).

Conflicts of Interest: The author declares no conflict of interest.

\section{Notes}

I owe great thanks to Thomas Lappi, Jessica Plant and the anonymous reviewers for critical comments on the text and Marcel Deckert for the formal editing.

2 On surfaces (and decoration) as interfaces, see Haug (2020, p. 531); on decoration as aesthetic work, see Haug (2020, p. 1)— referring to Böhme (2006, p. 26 f).

3 Bruno (1969); Corlaita Scagliarini (1974, pp. 7-10); Laidlaw (1985); Clarke (1991); Ling (1991); Barbet (2009); D'Auria (2010, 2011); Oriolo and Zanier (2011); Seiler (2011); D'Auria (2014); for a systematic collection of First Style examples of the Western Mediterranean, see Lappi (2020). For a comprehensive history of research, see Tarditi (2017); Lappi (2020, pp. 2-15).

4 In his monograph on the media character of images, Jones (2019, p. 40) discusses the First Style only in passing. Barry (2020) addresses the pictorial character of stones and discusses in this context also pictorial imitations of stones, especially marbles. He introduces important aspects on pictoriality and mediality (also for the First Style); however, without a systematic analysis of these aspects.

5 On the historicity of the two concepts, see Beyer and Spieß (2012); Haug (2015, pp. 9-29); Barham (2018); Platt (2018); Squire (2018, pp. 1-35). On the culturally specific construction of image and ornament, see Haug (2020, p. 540).

6 On the relative construction of image and ornament along the above-metioned parameters, see Haug (2020, p. 540), with bibliography.

7 For marble blocks, see Bruno (1969, p. 307); for veneer, see Mau (1907, p. 448 f.); see also McAlpine (2014, p. 85).

Haug (2015, p. 10 f.); Platt and Squire (2017, p. 3 f.).

Grave (2015, p. 29).

10 For false doors, see Bragantini (2003, pp. 189-91 Figures 5-7); Barbet (2009, p. 30 f.); Laidlaw (1985, p. 33). For false storeys, see Mau (1882, p. 32 f.); Dickmann (1999, p. 70); Leach (2004, p. 63); Bragantini (2003, p. 195 Figures 11 and 12); Aoyagi (1977, p. 118 f. Figure 62); (Haug 2020, 172 f.).

11 Haug (2020, p. 171 f.); see; Bragantini (2003, pp. 189-92 Figures 3, 5-8); see the upper floor in the atrium (A) of the Casa di C. Iulius Polybius (Haug 2020, p. 167 f. Figure 103) or the 'temple' architecture in the fauces of the Casa del Fauno (Haug 2020, p. 58 f. Figure 5); cf. Ling (1978, p. 16).

12 For the illusionary effect of false architecture, see Laidlaw $(1985$, p. 31 f.). 
See Clarke (1991, p. 34), who dates these illogical tendencies to the transition toward the Second Style; cf. Jones (2019, p. 41), who unconvincingly claims a random wall structure; Haug (2020, p. 181).

This, however, does not imply that the First Style is "overtly fictive", see Leach (2004, p. 60); Haug (2020, p. 541).

Bruno (1969, p. 310 f.); Ling (1972, p. 15); Rosenberg (2010, p. 107); Barry (2020, p. 94).

Haug (2020, p. 181).

Laidlaw (1985, pp. 25-28 with appendix pp. 334-37); cf. Laidlaw (1975, p. 44); for chronology, see Barbet (2009, p. 25 f.).

Haug (2020, p. 181. Figure 116).

Mau (1902, p. 180).

Barry (2020, p. 94). See also Barry (2020, p. 95): “The representation of the wall is an idealization (even heroization) of its material possibilities, lifting the prose of construction into a creative dimension where it becomes a thing of poetry".

Strässle (2014, p. 15) classifies this phenomenon as "Materialtransfer": 'Befreit' man ein Material von seinen qualitativphänomenal-funktionalen Attributen bzw. inszeniert man es in Kontrast—oder auch nur in Devianz-dazu, können daraus Ästhetiken resultieren, die weder dem imitierten noch dem imitierenden Material zuschreibbar sind, sondern unter der perspektive der Intermaterialität überhaupt erst in den Blick genommen werden können.

See, for the plastic differentiation of stucco cornices, Lappi (2020, pp. 130-35).

For this phenomenon in real architecture, see Grüner (2014, pp. 432 f., 435); Haug (2020, p. 538).

For examples outside of Pompeii, see Ling (1972, p. 18 f.).

D’Auria (2011, pp. 454-58 Pl. 24); cf. Lipps et al. (2018, p. 122).

Haug (2020, p. 100).

See Ling (1972, p. 22).

For the Logge building in Populonia, about twenty painted lithotypes—subtypes of alabaster, breccia, and marble-were identified; see Cavari and Donati (2014, p. 63 f.); Cavari et al. (2015, p. 57); more generally, see McAlpine (2014, p. 99).

With a definition of transmateriality Engels (2022): “[Transmateriality] discards the idea of clear directionalities between an authentic material prototype and a replica (and, with this, an 'origin' in a temporal sense), and embraces the notion of a design network featuring complex interdependencies” see also Strässle (2014, esp. pp. 12-16); Wolf (2016, esp. p. 105); (Flecker n.d.).

McAlpine (2014, pp. 99-103). In my opinion, however, it is futile to identify individual rock types precisely, as is often done in research. Thomas Lappi drew my attention to the fact that the respective quarries were not yet exploited on a larger scale in the First Style period. Therefore, veins, grains and the colouring were in fact just known from stone vessels and other small objects. For the ornamental character of the stone imitation, see Platt (2018, p. 259).

Sen. Ep. 86.6: operosa et in picturae modum variata circumlitio praetexitur; Mart. Ep. 8.55.6: marmore picta Nomas; Stat. Silv. 1.3.35 f.: marmora picturata lucentia vena; see Bradley (2006, p. 14); Platt (2018, p. 260); Barry (2020, p. 97).

Fant (2007, p. 336); Allag and Monier (2004, p. 356).

Haug (2020, p. 182).

See also McAlpine (2014, p. 91 f.); Haug (2020, pp. 55 f., 175); Lappi (2020, p. 126 f.).

Bruno (1969, p. 311); Ling (1991, p. 16).

Rosenberg (2010, p. 107); see also Haug (2020, p. 167).

E.g., the cubiculum (15) of the Casa dei Quattro Stili (I 8,17); Parise Badoni (1990, p. 895 Figure 79); Laidlaw (1985, Pl. 32b); see Haug (2020, p. 166).

Sampaolo (1993, p. 147 Figure 105).

For terminology, see Bauer (1962, p. 21); Haug (2020, p. 542).

For a comprehensive list of figurative representations in the Eastern and Western Mediterranean, see Lappi (2020, pp. 123 f., 179-181 Table 1 f.). Lappi's list of friezes, however, include also figurative scenes which are not part of a frieze but painted on ashlar blocks, see Lappi (2020, p. 124).

Gombrich (2002, p. 95 f.); Rosenberg (2010, p. 108); Haug (2020, p. 17).

Lappi (2020, pp. 142, 217).

Haug (2020, p. 172 f. Figure 108); for other plastic wall elements outside of Pompeii, see Ling (1972, p. 18 f.) and most recently, including Pompeii, Lappi (2020, p. 135 n. 1235).

Cassetta and Costantino (2006, pp. 327-30, Pls. 96 f. (with interpretation as a branch or a necklace)); Cassetta (2011, p. 475 with Pls. 29b, 30a); Pesando (2008, p. 167 Figure 9); D'Auria (2014, p. 57 f.).

E.g., for Domus VI 16,26-27, see Seiler (2011, p. 504 Pl.s 31c. 32a-c).

Gallo and Iorio (2007); Haug (2020, p. 179). 


\section{References}

Allag, Claudine, and Florence Monier. 2004. La représentation des roches décoratives dans la peinture murale romaine. In Les Roches Décoratives dans l'Architecture Antique et du Haut Moyen Âge [Actes du Colloque d'Autun]. Edited by Pascale Chardron-Picault, Pierre

Rat and Jaqueline Lorenz. Paris: Comité des Travaux Historiques et Scientifiques, pp. 355-68.

Sampaolo (2009, p. 1013 Figures 98 f.); de Vos Raaijmakers (1977, p. 35); Laidlaw (1985, pp. 34, 276 f. Figure 68); Gallo and Iorio (2007, esp. p. 37); Gallo (2015, p. 49).

Gallo and Iorio (2007, p. 31 f.) suggest different groups of motifs. Indeed, the stayr and muse are situated close together. For the western wall, however, I question the idea that the group of four pictures is inspired by the "sfera del mondo agonistico". Additionally, I maintain that interpreting the swordsman and the women next to him as dominus and domina strains the picture too much; see Haug (2020, p. 180).

Similarly Barry (2020, p. 100 (using the example of the painted 'relief' in the Alexander exedra of the Casa del Fauno)).

For the concept of remediation, see Bolter and Grusin (2000, esp. pp. 22 f., 31 f.).

Examples can be found in Eristov (1979).

For this process, Bolter and Grusin (2000, esp. pp. 21-62) coined the term remediation, "oscillating between immediacy (the total effacement of a medium) and hypermediacy (the marking out of mediation)" (Plant 2022, p.117 n. 20).

Mau (1882, p. 43).

Staub-Gierow (1994, p. 65 f.); Staub-Gierow (1997, p. 91 Figure 41); Laidlaw (1985, pp. 251 f. Figure 65); Oriolo and Zanier (2011, $488 \mathrm{f}$. assign the decorative elements of the first style to a redesign in early Augustan times); furthermore the western rear wall of peristyle (y) of the Casa di M. Epidius Sabinus (IX 1,22.29) also features half columns; see Sampaolo (2009, pp. 994-96, Figure 69).

For measures, see Strocka (1991, pp. 27, 29).

Mau (1902, pp. 157-71).

Haug (2020, p. 184).

Haug (2020, p. 536).

The darkness of the tablinum of the Casa di Marcus Lucretius Fronto that limited the view to the upper zone, as postulated by Schmaltz (1989, p. 222 f.), cannot be confirmed. Even today, despite the reconstructed roof, the lighting conditions seem to correspond with those in Antiquity.

Haug (2020, p. 535 f.).

For undifferentiated plinth zones, see Casa del Fauno's (VI 12) vestibulum (5/26), fauces (IV/38), and cubiculum ((17/28) and $(9 / 31))$, which are coloured in yellow, and the western atrium's alae and oecus (31/44) coloured in green, as well as cubiculum $(10 / 31)$ and triclinium (12/35) in violet; Haug (2020, p. 158).

See, e.g., Casa del Fauno's (VI 12) tablinum (13/33) and triclinia ((14/34) and (12/35)), as well as the exedra of Alexander (30/42) and the fauces (7/53); Haug (2020, p. 164).

For belts, see, e.g., Casa del Fauno's (VI 12) vestibulum (5/26), fauces (IV/38), cubiculum (9/31), and tablinum (13/33); for fasciae, see Casa di M.s Pupius Rufus's (VI 15,5) ala (g); for kyma reversa, see Casa del Fauno's (VI 12) southern peristyle (I/36); Haug (2020, pp. 85 f., 158, 170).

As can be seen in the Casa del Fauno's (VI 12) western atrium and domus's (I 20,4) cubiculum (7) and Casa di Sallustio's (VI 2,4) oecus (22). Haug (2020, p. 175).

See Casa del Fauno (VI 12), exedra of Alexander; Mau (1882, p. 51); de Vos Raaijmakers (1977, p. 35).

Haug (2020, p. 184 f. Figure 2. 6).

Rosenberg (2010, p. 107).

Wollheim (2003). With regard to media theory, see Engell and Vogl (2000, p. 10): “Media make something legible, audible, visible, perceivable, while simultaneously erasing itself and its constitutive involvement in this sensuality, thus becoming unperceivable, anesthetic". Referring to this quote, see Krämer (2015, p. 31): "At the same time that media bring something forth, they themselves recede into the background; media enable something to be visualised, while simultaneously remaining invisible. Additionally, vice versa: only noise, dysfunction and disturbance make the medium itself noticeable"; for Roman paintings, see Jones (2019, pp. 152-54).

See also Jones (2019, p. 156 f.).

Bolter and Grusin (2000, p. 21): "Virtual reality is immersive, which means that it is a medium whose purpose is to disappear". See Boehm (1978, pp. 118-38).

With regard to later styles (which intensify the play with different media in the sense of metapictoriality), see Jones (2019, p. 137 f.); for stucco design strategies, see Plant (2022). 
Aoyagi, Masanori. 1977. La Casa della Nave Europa a Pompei. Tokio: Institute for the Study of Cultural Exchange, Faculty of Letters, the University of Tokyo.

Barbet, Alix. 2009. La Peinture Murale Romaine: Les Styles Décoratifs Pompéiens, 2nd ed. Paris: Picard.

Barham, Nicola. 2018. Esteemed ornament: An overlooked value for approaching Roman visual culture. In Ornament and Figure in Graeco-Roman Art: Rethinking Visual Ontologies in Classical Antiquity. Edited by Nikolaus Dietrich and Michael Squire. Berlin: De Gruyter, pp. 279-98.

Barry, Fabio. 2020. Painting in Stone. Architecture and the Poetics of Marble from Antiquity to the Enlightenment. New Haven: Yale University Press.

Bauer, Hermann. 1962. Rocaille: Zur Herkunft und zum Wesen eines Ornament-Motivs. Berlin: De Gruyter.

Beyer, Vera, and Christian Spieß, eds. 2012. Einleitung. Ornamente und ornamentale Modi des Bildes. In Ornament. Motiv—ModusBild.. München: Wilhelm Fink, pp. 13-23.

Boehm, Gottfried. 1978. Zu einer Hermeneutik des Bildes. In Die Hermeneutik und die Wissenschaften. Edited by Hans Georg Gadamer and Gottfried Boehm. Frankfurt: Suhrkamp, pp. 444-71.

Böhme, Gernot. 2006. Architektur und Atmosphäre. München: Wilhelm Fink Verlag.

Bolter, Jay David, and Richard Grusin. 2000. Remediation: Understanding New Media. Cambridge: The MIT Press.

Bradley, Marc. 2006. Colour and Marble in Early Imperial Rome. PCPhS 52: 1-22. [CrossRef]

Bragantini, Irene. 2003. Pompei: Pitture e Mosaici. Rome: Union Printing, X. pp. 183-356 s.v. "IX 13,1-3, Casa di Polibio".

Bruno, Vincent J. 1969. Antecedents of the Pompeian First Style. AJA 73: 305-17. [CrossRef]

Cassetta, Roberto. 2011. Un raro fregio figurato di I stile dalla Casa del Naviglio (VI 10, 11) di Pompei. In Pittura Ellenistica in Italia e in Sicilia. Linguaggi e Tradizioni. Atti del Convegno di Studi, Messina, 24-25. Settembre 2009. Edited by Gioacchino Francesco La Torre and Mario Torelli. Rom: L'Erma di Bretschneider, pp. 473-79.

Cassetta, Roberto, and Claudia Costantino. 2006. Parte V: La Casa del Naviglio (VI, 10,11) e le botteghe VI, 10,10 e VI, 10,12. In Rileggere Pompei 1: L'insula 10 della Regio VI. Edited by Filippo Coarelli and Fabrizio Pesando. Roma: L'Erma di Bretschneider, pp. $243-333$.

Cavari, Fernanda, and Fluvia Donati. 2014. Rappresentazioni e composizione delle imitazioni marmoree nella pittura di I Stile dall'Etruria romana. In Antike Malerei Zwischen Lokalstil und Zeitstil, Akten des XI. Internationalen Kolloquiums AIPMA, 13-17. September 2010 in Ephesos. Edited by Norbert Zimmermann. Wien: Verlag der Österreichischen Akademie der Wisssenschaften, pp. 63-73.

Cavari, Fernanda, Francesca Droghini, Marco Giamello, Cynthia Mascione, and Andrea Scala. 2015. The Imitation of Coloured marbles in a First Style Wall Painting from the Etruscan-Roman town of Populonia (LI-Italy). In Interdisciplinary Studies on Ancient Stone, ASMOSIA X. Proceedings of the Tenth International Conference of ASMOSIA Association for the Study of Marble E Other Stones in Antiquity, Rome, 21-26 May 2012. Edited by Patrizio Pensabene and Eleonora Gasparini. Rom: L'Erma di Bretschneider, pp. 55-62.

Clarke, John R. 1991. The Houses of Roman Italy, 100 B.C.-A.D. 250: Ritual, Space, and Decoration. Berkeley: University of California Press. Corlaita Scagliarini, Daniela. 1974. Spazio e decorazione nella pittura pompeiana. Palladio XXIII-XXV: 3-44.

D'Auria, Doria. 2010. La Casa del Granduca Michele (VI, 5, 5-6). In Rileggere Pompei 3. Ricerche Sulla Pompei Sannitica. Campagne di Scavo 2006-2008, Quaderni di Studi Pompeiani 4. Edited by Fabrizio Pesando. Rome: L’Erma di Bretschneider, pp. 41-54.

D'Auria, Dora. 2011. La Protocasa del Granduca Michele (VI, 5, 5): Funzionalità degli ambienti, tipologie edilizie edecorazioni parietali. In Pittura Ellenistica in Italia e in Sicilia: Linguaggi e Tradizioni. Atti del Convegno di Studi, Messina, 24-25. Settembre 2009. Edited by Gioacchino Francesco La Torre and Mario Torelli. Rome: L'Erma di Bretschneider, pp. 447-58.

D'Auria, Dora. 2014. Gli apparati decorativi delle case di livello medio a Pompei in età ellenistica. In Antike Malerei zwischen Lokalstil und Zeitstil. Akten des XI. Internationalen Kolloquiums der AIPMA, 13-17 September 2010 in Ephesos. Edited by Norbert Zimmermann. Wien: Verlag der Österreichischen Akademie der Wissenschaften, pp. 55-62.

de Vos Raaijmakers, Mariette. 1977. Primo stile figurato e maturo quarto stile negli scarichi provenienti dalle macerie del terremoto del 62 d.C. a Pompei. MededRom 39: 29-47.

Dickmann, Jens-Arne. 1999. Domus Frequentata: Anspruchsvolles Wohnen im Pompejanischen Stadthaus. München: Pfeil.

Engell, Lorenz, and Joseph Vogl. 2000. Vorwort. In Kursbuch Medienkultlingur: Die maßgeblichen Theorien von Brecht bis Baudrillard. Edited by Claus Pias, Joseph Vogl, Lorenz Engell and Britta Neitzel. Stuttgart: Deutsche Verlags-Anstalt, pp. 8-11.

Engels, Benjamin. 2022. Roman Basket Urns as Elements in a Transmaterial Design System. In Materiality in Roman Art and Architecture. Edited by Annette Haug, Adrian Hielscehr and Taylor Lauritsen. Berlin: De Gruyter, pp. 245-63.

Eristov, Hèlène. 1979. Corpus des faux-marbres peints à Pompéi. MEFRA 91: 693-771. [CrossRef]

Fant, Clayton J. 2007. Real and Painted (Imitation) Marble at Pompeii. In The World of Pompeii. Edited by John J. Dobbins and Pedar W. Foss. London and New York: Routledge, pp. 336-46.

Flecker, Manuel. n.d. In print. An Age of Intermateriality: Skeuomorphism and Intermateriality Between the Late Republic and Early Empire. In Materiality in Roman Art and Architecture. Edited by Annette Haug, Adrian Hielscehr and Taylor Lauritsen. Berlin: De Gruyter, pp. 265-83.

Gallo, Alessandro. 2015. Il progetto architettonico strutturale della Casa di M. Epidio Sabino a Pompei (IX 1, 22-29) Parte seconda: Catalogo analitico degli ambienti. RSP 26/27: 35-52. 
Gallo, Alessandro, and Vincenca Iorio. 2007. Le bugne figurate della Parete N dell'oecus b1 della Casa IX, 1, 22-29 (cd di M. Epidio Sabino): Una testimonianza poco nota di pittura ellenistica pompeiana ed i relativi problemi di committenza. Quaderni di Studi Pompeiani 1: 27-46.

Gombrich, Ernst H. 2002. The Sense of Order: A Study in the Psychology of Decorative Art. Oxford: Phaidon Press.

Grave, Johannes. 2015. Architekturen des Sehens. Bauten in Bildern des Quattrocento. Paderborn: Wilhelm Fink Verlag.

Grüner, Andreas. 2014. Vom Sinn zur Sinnlichkeit: Probleme und Perspektiven des Ornamentbegriffs in der antiken Architektur. In Antike Bauornamentik. Grenzen und Möglichkeiten ihrer Erforschung. Kolloquium München, 13-15 Oktober 2011. Edited by Johannes Lipps and Dominik Maschek. Wiesbaden: Reichert, pp. 25-51.

Haug, Annette. 2015. Bild und Ornament im frühen Athen. Regensburg: Schnell \& Steiner.

Haug, Annette. 2020. Decor-Räume in Pompejanischen Stadthäusern: Ausstattungsstrategien und Rezeptionsformen, Decor 1. Berlin and Boston: De Gruyter.

Jones, Nathaniel B. 2019. Painting, Ethics and Aesthetics in Rome. Cambridge: Cambridge University Press.

Krämer, Sybille. 2015. Medium, Messenger, Transmission: An Approach to Media Philosophy. Amsterdam: Amsterdam University Press.

Laidlaw, Anne. 1975. A Reconstruction of the First Style Decoration in the Alexander Exedra of the House of the Faun. In Neue Forschungen in Pompeji und den Anderen vomVesuvausbruch 79 n. Chr. Verschütteten Städten. Internationales Kolloquium Essen 11-14, Juni 1973. Edited by Bernard Andreae and Helmut Kyrieleis. Recklinghausen: Bongers, pp. 39-52.

Laidlaw, Anne. 1985. The First Style in Pompeii: Painting and Architecture. Rome: G. Bretschneider.

Lappi, Thomas. 2020. Hellenistische Wanddekorationen: Syntax, Semantik und Chronologie des Ersten Stils im Westlichen Mittelmeerraum. Wiesbaden: Reichert.

Leach, Eleanor W. 2004. The Social Life of Painting in Ancient Rome and on the Bay of Naples. Cambridge: Cambridge University Press.

Ling, Roger. 1972. Stucco Decoration in Pre-Augustan Italy. PBSR 40: 11-57. [CrossRef]

Ling, Roger. 1978. Etruscan and Early Roman Architecture. Harmondsworth: Penguin Books.

Ling, Roger. 1991. Roman Painting. Cambridge: Cambridge University Press.

Lipps, Johannes, Heinrich Piening, and Laura Thiemann. 2018. Die Stuckdecke des „oecus Tetrastylus“ aus dem sog. Augustushaus auf dem Palatin im Kontext antiker Deckenverzierungen. Rahden: Marie Leidorf.

Mau, August. 1882. Geschichte der Decorativen Wandmalerei in Pompeji I. Berlin: Reimer.

Mau, August. 1902. Wandschirm und Bildträger in der Wandmalerei. MDAI(R) 17: 179-231.

Mau, August. 1907. Pompeji: In Leben und Kunst. Leipzig: Wilhelm Engelmann.

McAlpine, Lynley J. 2014. Marble, Memory, and Meaning in the Four Pompeian Styles of Wall Painting. Ph.D. thesis, University of Michigan, Ann Arbor, MI, USA. Available online: https:/ / deepblue.lib.umich.edu/handle/2027.42/107074 (accessed on 6 July 2021).

Oriolo, Flaviana, and Katharina Zanier. 2011. Decorazioni di primo stile nei peristili e giardini di Pompei. In Pittura Ellenistica in Italia e in Sicilia: Linguaggi e Tradizioni. Atti del Convegno di Studi, Messina, 24-25 Settembre 2009. Edited by Gioacchino Francesco La Torre and Mario Torelli. Rom: L'Erma di Bretschneider, pp. 481-97.

Parise Badoni, Franka. 1990. Pompei: Pitture e Mosaici. Rome: Arti Grafiche Pizzi, I. pp. 847-913 s. v. "I 8,17, Casa dei Quattro Stili".

Pesando, Fabrizio. 2008. Case di età medio-sannitica nella Regio VI: Tipologia edilizia e apparati decorative. In Nuove Ricerche Archeologiche Nell'area Vesuviana (scavi 2003-06). Atti del Convegno Internazionale, Roma 1-3 Febbraio 2007. Edited by Pier Giovanni Guzzo and Maria Paola Guidobaldi. Rom: L'Erma di Bretschneider, pp. 159-72.

Plant, Jessica. 2022. Hard as Rock and Light as Air: Stucco Ceilings in Roman Domestic Space. In Materiality in Roman Art and Architecture. Aesthetics, Semantics and Function. Edited by Annette Haug, Adrian Hielscher and M. Taylor Lauritsen. Berlin: De Gruyter, pp. 113-29.

Platt, Verity. 2018. Of Sponges and Stones. Matter and Ornament in Roman Painting. In Ornament and Figure in Graeco-Roman Art: Rethinking Visual Ontologies in Classical Antiquity. Edited by Nikolaus Dietrich and Michael Squire. Berlin: De Gruyter, pp. 241-78.

Platt, Verity, and Michael Squire, eds. 2017. Framing the Visual in Greek and Roman Antiquity: An Introduction. In The Frame in Classical Art: A Cultural History. Cambridge: Cambridge University Press, pp. 3-99.

Rosenberg, Angele. 2010. Taking the First Style Seriously. Chicago Art Journal 20: 103-15.

Sampaolo, Valeria. 1993. Pompei: Pitture e Mosaici. Rome: Arti Grafiche Pizzi, IV, pp. 87-147 s.v. "VI 2,4, Casa di Sallustio".

Sampaolo, Valeria. 2009. Pompei: Pitture e Mosaici. Rome: Arti Grafiche Pizzi, VIII, pp. 956-1044 s.v. “IX 1,22.29, Casa di M. Epidius Sabinus".

Schmaltz, Bernhard. 1989. Der 2. pompejanische Stil: Zur Eigenart einer Dekorationsweise und zum Verhältnis einer Entwicklungsstufe. Gymnasium 96: 217-38.

Seiler, Florian. 2011. Questioni intorno ad un complesso di pitture ellenistiche singolari a Pompei. In Pittura Ellenistica in Italia e in Sicilia. Linguaggi e Tradizioni. Atti del Convegno di Studi, Messina, 24-25 Settembre 2009. Edited by Gioacchino Francesco La Torre and Mario Torelli. Rom: L'Erma di Bretschneider, pp. 499-517.

Squire, Michael. 2018. 'To haunt, to startle, and way-lay': Approaching ornament and figure in Graeco-Roman art. In Ornament and Figure in Graeco-Roman Art. Edited by Nikolaus Dietrich and Michael Squire. Berlin: De Gruyter, pp. 1-35.

Staub-Gierow, Margaretha. 1994. Casa del Granduca (VII 4,56) und Casa die Capitelli figurati (VII 4,57). Munich: Hirmer.

Staub-Gierow, Margaretha. 1997. Pompei: Pitture e Mosaici. Rome: Arti Grafiche Pizzi, VII, pp. 63-92 s.v. “VII 4,57, Casa die Capitelli figurati". 
Strässle, Thomas. 2014. Pluralis materialitatis. In Das Zusammenspiel der Materialien in den Künsten. Theorien-Praktiken-Perspektiven. Edited by Thomas Strässle, Christoph Kleinschmidt and Johanne Mohs. Bielefeld: Transcript, pp. 7-23.

Strocka, Volker Michael. 1991. Casa del Labirinto (VI 11, 8-10). Munich: Hirmer.

Tarditi, Chiara. 2017. La decorazione parietale di tipo architettonico. Proposta per una ridefinizione. Aevum 91: 55-77.

Wolf, Gerhard. 2016. Vesting Walls, Displaying Structure, Crossing Cultures. Transmedial and Transmaterial Dynamics of Ornament. In Histories of Ornament. From Global to Local. Edited by Gülru Necipoğlu and Alina Payne. Princeton: Princeton University Press, pp. 96-105.

Wollheim, Richard. 2003. In Defense of Seeing-In. In Looking into Pictures: An Interdisciplinary Approach to Pictorial Space. Edited by Heiko Hecht, Robert Schwartz and Margaret Atherton. Cambridge: Cambridge University Press, pp. 3-16. 